Western Washington University

Western CEDAR

\title{
Democracy, Institutions and Attitudes about Citizen Influence on Government
}

Todd Donovan

Western Washington University, todd.donovan@wwu.edu

Shaun Bowler

Follow this and additional works at: https://cedar.wwu.edu/politicalscience_facpubs

Part of the Political Science Commons

\section{Recommended Citation}

Donovan, Todd and Bowler, Shaun, "Democracy, Institutions and Attitudes about Citizen Influence on Government" (2002). Political Science Faculty Publications. 6.

https://cedar.wwu.edu/politicalscience_facpubs/6 


\section{CAMBRIDGE UNIVERSITY PRESS}

Democracy, Institutions and Attitudes about Citizen Influence on Government Author(s): Shaun Bowler and Todd Donovan

Source: British Journal of Political Science, Vol. 32, No. 2 (Apr., 2002), pp. 371-390

Published by: Cambridge University Press

Stable URL: http://www.jstor.org/stable/40922 23

Accessed: 23/10/2014 16:46

Your use of the JSTOR archive indicates your acceptance of the Terms \& Conditions of Use, available at http://www.jstor.org/page/info/about/policies/terms.jsp

JSTOR is a not-for-profit service that helps scholars, researchers, and students discover, use, and build upon a wide range of content in a trusted digital archive. We use information technology and tools to increase productivity and facilitate new forms of scholarship. For more information about JSTOR, please contact support@jstor.org. 


\title{
Democracy, Institutions and Attitudes about Citizen Influence on Government
}

\author{
SHAUN BOWLER AND TODD DONOVAN*
}

\begin{abstract}
Theorists such as Carole Pateman and Benjamin Barber suggest that democratic participation will engage citizens and lead them to have more positive regard for political processes and democratic practices. The American states provide a setting where provisions for direct voter participation in legislation vary substantially. If participatory institutions have an 'educative role' that shapes perceptions of government, then citizens exposed to direct democracy may be more likely to claim they understand politics and be more likely to perceive that they are capable of participation. They may also be more likely to perceive that government is responsive to them. We merge data on state-level political institutions with data from the 1992 American National Election Study to test these hypotheses with OLS models. Our primary hypotheses find support. We present evidence that the effects of exposure to direct democracy on internal and external political efficacy rival the effects of formal education.
\end{abstract}

Recent scholarship has sought to understand citizen attitudes about government and high levels of cynicism about democratic politics. ${ }^{1}$ Much of this work has considered the impact of socio-demographic changes over the past generation. Some work in this area has extended our understanding of attitudes towards government by incorporating the effects of institutional arrangements themselves. An important component of these explanations has been the link between voter assessments of institutions and whether the voter 'wins' or 'loses' under those institutions. In shaping how fully someone may win or lose, and most

* Department of Political Science, University of California Riverside; and Department of Political Science, Western Washington University, respectively. Earlier versions of this article were presented at the Pacific Northwest Political Science Association, Eugene, Oregon, 1999, and the Midwest Political Science Association meeting, Chicago, 2000. Authorship is equal. Direct correspondence to T. Donovan, Department of Political Science, Western Washington University, Bellingham, WA 98552, USA.

1 Pippa Norris, Critical Citizens: Global Support for Democratic Governance (Oxford: Oxford University Press, 1999); Marc Hetherington, 'The Effect of Political Trust on the Presidential Vote, 1968-96', American Political Science Review, 93 (1999), 311-26; Ola Listhaug, 'Confidence in Political Institutions: Norway, 1982-1996' (paper presented at the Centre for Nordic Policy Studies, Aberdeen, 1998); Stephen Craig, Broken Contract? Changing Relationships Between Americans and their Government (Boulder, Colo.: Westview Press, 1996); Stephen Craig, The Malevolent Leaders: Popular Discontent in America (Boulder, Colo.: Westview Press, 1993); John Hibbing and Elizabeth Theiss-Morse, Congress as Public Enemy (Cambridge: Cambridge University Press, 1995); M. Kaase and K. Newton, Beliefs in Government (Oxford: Oxford University Press, 1995); Hans-Dieter Klingeman and Dieter Fuchs, Citizens and the State (Oxford: Oxford University Press, 1995). 
especially in determining how badly someone loses, institutions themselves colour how voters may view the political process. ${ }^{2}$

Much, but not all, of this work has been cross-national in scope. In part this is because worries over growing cynicism about politics seemingly affect the industrial democracies in general. ${ }^{3}$ Cross-national studies allow for variation in institutional setting and so allow scholars to test institutionally based explanations. We follow the work of Frey ${ }^{4}$ and Frey and Stutzer ${ }^{5}$ to examine the question of whether institutional variation within one country, in this case the United States, can help explain variation in individual attitudes about a citizen's capacity to influence what governments do. Like Mendelsohn and Cutler $^{6}$ and Frey and Stutzer, we examine the institution of direct democracy and the contribution it makes to citizen attitudes about influencing government.

The main hypothesis of interest in what follows is that exposure to more frequent use of state-level direct democracy can cause citizens to have more positive attitudes about their abilities to influence the political system, and to have more positive attitudes about how government responds to them. Attitudinal measures of this capacity, or efficacy, are usually separated conceptually into two categories of internal and external efficacy. ${ }^{7}$ In short, we test whether citizens who are frequently exposed to decisions made by ballot initiative are more likely to see themselves as having resources and skills that allow them to influence what government does (internal efficacy), and whether they are more likely to see that government responds to them (external efficacy). Political efficacy is of interest here because it can play an important role in shaping a wide range of attitudes and behaviour. Internal efficacy represents a sense of 'being capable of acting effectively in the political realm', ${ }^{8}$ and external

2 Chris Anderson and Christine Guillory, 'Political Institutions and Satisfaction with Democracy: A Cross-National Analysis of Consensus and Majoritarian Systems', American Political Science Review, 91 (1997), 66-81; Chris Anderson and Andrew LoTempio, 'Winning, Losing and Political Trust in America', British Journal of Political Science, 32 (2002), 335-51; Stacy Gordon and Gary Segura, 'Cross National Variation in the Political Sophistication of Individuals: Capability of Choice?' Journal of Politics, 59 (1997), 126-47; Ola Listhaug and M. Wiberg, 'Confidence in Political and Private Institutions' in Klingeman and Fuchs, eds, Citizens and the State; Harold Clarke and Alan Acock, 'National Elections and Political Attitudes: The Case of Political Efficacy', British Journal of Political Science, 19 (1989), 551-62.

3 Norris, Critical Citizens.

4 Bruno Frey, 'A Constitution for Knaves Crowds Out Civic Virtues', Economic Journal, 107 (1997), 1043-53.

5 Bruno Frey and Alois Stutzer, 'Happiness, Economy and Institutions' (Institute for Empirical Research in Economics, University of Zurich, Working Paper No. 15, 1999).

${ }^{6}$ Matthew Mendelsohn and Fred Cutler, 'The Effect of Referendums on Democratic Citizens: Knowledge, Politicization, Efficacy and Tolerance', British Journal of Political Science, 30 (2000), 685-98.

7 Robert Lane, Political Life: Why and How People Get Involved in Politics (New York: Free Press, 1959); George Balch, 'Multiple Indicators in Survey Research: The Concept of "Sense of Political Efficacy" ', Political Methodology, 1 (1974), 1-43; Stephen Craig and Michael Maggiotto, 'Measuring Political Efficacy', Political Methodology, 8 (1982), 85-110.

${ }^{8}$ Steven Finkel, 'Reciprocal Effects of Participation on Political Efficacy: A Panel Analysis', American Journal of Political Science, 29 (1985), 289-314, p. 289. 
efficacy has been found to affect political trust, ${ }^{9}$ system support, ${ }^{10}$ and electoral participation. $^{11}$

Carole Pateman contends that democratic participation has an 'educative' role in the workplace, and writes of 'the human results that accrue through the participatory process'. ${ }^{12}$ To Pateman, these results include increased selfconfidence for individuals and acquisition of the skills that citizens needed to participate, both of which comprise internal political efficacy. Other theorists suggest that political participation might simply instill passive acceptance of a regime - particularly in a standard electoral context where voters choose between parties or candidates. Electoral participation may thus promote feelings of system legitimacy and governmental responsiveness, affecting external efficacy but not internal efficacy. ${ }^{13}$ As we discuss below, however, there are solid theoretical reasons to expect that initiative and referendum elections present a context that is distinct from standard candidate and party elections, and that direct democracy can thus affect both internal and external political efficacy.

\section{DIRECT DEMOCRACY AND CIVIC ENGAGEMENT}

Many of the debates over direct democracy have concerned normative questions about the relative merits of direct versus representative democracy. This, in turn, has been tied to the related questions of whether or not direct democracy produces good or bad public policy, and whose interests it serves. ${ }^{14}$ Regardless

${ }^{9}$ Stephen Craig, 'Efficacy, Trust and Political Behavior: An Attempt to Resolve a Lingering Conceptual Dilemma', American Politics Quarterly, 7 (1979), 225-39.

${ }^{10}$ Shanto Iyengar, 'Subjective Political Efficacy as a Measure of Diffuse Support', Public Opinion Quarterly, 44 (1980), 249-56.

${ }^{11}$ Stephen Shaffer, 'A Multivariate Explanation of Decreasing Turnout in Presidential Elections, 1960-1976', American Journal of Political Science, 25 (1981), 68-96; Paul Abramson and John Aldrich, 'The Decline of Electoral Participation in America', American Political Science Review, 76 (1982), 592-621.

${ }^{12}$ Carole Pateman, Participation and Democratic Theory (Cambridge: Cambridge University Press, 1970), pp. 24-5. It is important to note that Pateman makes no claims that large-scale participation in the electoral arena could produce the same effects as small (workplace) settings that allow for discussion and personal interactions. We distil our hypothesis from her theory, and from proponents of mass-level direct democracy noted below. We do not claim that participation on ballot initiative questions can have the same qualitative effects on efficacy as small-scale democratic participation.

${ }^{13}$ See, for example, Benjamin Ginsberg, The Consequences of Consent: Elections, Citizen Control and Popular Acquiescence (Reading, Mass.: Addison-Wesley, 1982), at p. 182. For empirical evidence from candidate elections, see Finkel, 'Reciprocal Effects of Participation on Political Efficacy'.

${ }^{14}$ For an extensive review of these debates, see Elizabeth Gerber, The Populist Paradox: Interest Group Influence and the Promise of Direct Legislation (Princeton, NJ: Princeton University Press, 1999); Shaun Bowler and Todd Donovan, Demanding Choices: Opinion and Voting in Direct Democracy (Ann Arbor: University of Michigan Press, 1998); Thomas Cronin, Direct Democracy: The Politics of Initiative, Referendum and Recall (Cambridge, Mass: Harvard University Press, 1989); David Magleby, Direct Legislation: Voting on Ballot Propositions in the US (Baltimore, Md: Johns Hopkins University Press, 1984). 
of academic conclusions about the merits of the process, there is substantial evidence of high levels of public satisfaction with direct democracy. Surveys of citizens in California, ${ }^{15}$ Washington, ${ }^{16}$ Oregon, ${ }^{17}$ and Florida ${ }^{18}$ find over two-thirds of respondents having favourable attitudes towards their state's initiative process.

Other strands of discussions over the value of direct democracy, at least among proponents, have sought to emphasize the role it will play in motivating and energizing a sense of civic engagement and participation. ${ }^{19}$ It is an argument clearly in keeping with a long-held tradition from classical democratic theory that participation is not just of value in and of itself, but that it also has an educative role that promotes civic engagement and wider virtues. ${ }^{20}$ Similar themes have been echoed at least since de Tocqueville's observation that citizens learn political skills via participation in voluntary organizations. ${ }^{21}$ Almond and Verba's study of citizen attitudes, for example, found that experiences with democratic decision making in schools or in families were related to adult participation in politics and to the belief that individuals can influence government. The effect held for citizens in Britain, Germany, Italy and Mexico. $^{22}$

As applied to contemporary direct democracy, the anticipated effects of participation have often been couched in terms of an expected favourable impact on turnout rates ${ }^{23}$ and increased civic engagement. ${ }^{24}$ Hard data, however, has

${ }^{15}$ Michael Hagen and Edward Lascher, 'Public Opinion about Direct Democracy' (paper presented at the Annual Meeting of the American Political Science Association, Boston, 1998); Jack Citrin, 'Who's the Boss? Direct Democracy and Popular Control of Government', in Stephen Craig, ed., Broken Contract (Boulder, Colo.: Westview Press, 1996), pp. 268-93, at p. 272.

${ }^{16}$ Authors' annual statewide survey (1999), on file.

17 Tim Hibbits, Oregon Public Opinion Polls, on file with authors (1999).

18 Stephen Craig, Aimee Kreppel and J. Kane, 'Public Opinion and Direct Democracy: A Case Study', in Matthew Mendelsohn and Andrew Parkin, eds, Referendum Democracy: Citizens, Elites and Deliberation in Referendum Campaigns (Basingstoke, Hants.: Palgrave, 2001), pp. 25-46.

${ }^{19}$ Benjamin Barber, Strong Democracy: Participatory Politics for a New Age (Berkeley: University of California Press, 1984); Ian Budge, The New Challenge of Direct Democracy (Cambridge: Cambridge University Press, 1996).

${ }^{20}$ Pateman, Participation and Democratic Theory, p. 25; Michael Morell, 'Citizens' Evaluations of Participatory Democratic Procedures: Normative Theory Meets Empirical Science', Political Research Quarterly, 52 (1999), 293-322.

${ }^{21}$ Alexis de Tocqueville, Democracy in America: Volume II, translated by Henry Reeve, Phillips Bradley, ed. (New York: Alfred A. Knopf, 1945 [1840], pp. 114-18; Also see Robert Putnam, Making Democracy Work: Civic Traditions in Modern Italy (Princeton, NJ: Princeton University Press, 1993).

${ }^{22}$ Gabriel Almond and Sidney Verba, The Civic Culture (Princeton, NJ: Princeton University Press, 1963).

${ }^{23}$ Barber, Strong Democracy, pp. 235-6; Cronin, Direct Democracy, p. 11; Budge, The New Challenge of Direct Democracy; David Butler and Austin Ranney, Referendums Around the World: The Growing Use of Direct Democracy (Washington, DC: AEI Press, 1994), pp. 15-16.

${ }^{24}$ Barber, Strong Democracy, pp. 284-5; David Schmidt, Citizen Lawmaking: The Ballot Initiative Revolution (Philadelphia, Penn.: Temple University Press, 1989). 
cast some doubt on the stimulating effects of direct democracy on turnout. ${ }^{25}$ The more subtle effects of direct democracy on citizen attitudes about politics in the United States has rarely been tested, ${ }^{26}$ and studies of the effects of participation in legislative and executive elections in West Germany and the United States found that the act of voting might lead citizens to have a sense of greater governmental responsiveness, but that it does not cause feelings of increased political competence (internal efficacy) ${ }^{27} \mathrm{~A}$ rare empirical test of Pateman's theory in the workplace, however, found that greater democratization in industrial work settings was associated with higher levels of political efficacy. ${ }^{28}$

Although exposure to referendum questions may not have the same educative effects as workplace democracy, it is reasonable to expect that referendums could have a greater effect on efficacy than elections to select representatives, as these latter decisions mediate the relationship between the citizen and policy outcomes. Work on Switzerland, ${ }^{29}$ for example, found signs of greater civic virtues and even happiness (in an attitudinal sense) in cantons that used direct, rather than just representative, democracy. Mendelsohn and Cutler also found evidence that the mass public learned about constitutional questions during the 1992 Charlottetown Constitutional Accord in Canada, but they found no effect on efficacy. ${ }^{30}$ To be sure, these more general and attitudinal arguments have been presented before in the United States. Cronin, for example, notes one of the early arguments favouring direct democracy was that 'giving the citizen more of a role in governmental processes might lessen alienation and apathy' ${ }^{31}$

A key point here is that there have been no systematic tests of these more subtle effects of direct democracy in the setting of the United States, where the citizen's initiative device is used quite frequently. The issue of whether or not direct democracy has any effect on civic engagement has relevance to wider

${ }^{25}$ Cronin, Direct Democracy, pp. 227-8; Magleby, Direct Legislation, pp. 96-8; D. Everson, 'The Effects of Initiatives on Voter Turnout: A Comparative State Analysis', Western Political Quarterly, 34 (1981), 415-25. Studies that do show a relationship between initiatives and turnout include Mark Smith, 'Ballot Initiatives, Voter Interest, and Turnout' (paper presented at the annual meeting of the Western Political Science Association, Seattle, 1999); Caroline Tolbert, John Gummel and Daniel Smith, 'The Effects of Ballot Initiatives on Voter Turnout in the American States' (paper presented at the annual meeting of the American Political Science Association, Washington, DC, 2000).

${ }^{26}$ For null findings at the bivariate level from the United States, see Citrin, 'Who's the Boss?' On Canada, see Mendelsohn and Cutler, 'The Effect of Referendums on Democratic Citizens'.

${ }^{27}$ For claims about the limited effects of representative elections on self-perceived competence (internal efficacy), see Finkel, 'Reciprocal Effects of Participation on Political Efficacy', at p. 908; Steven Finkel, 'The Effects of Participation on Political Efficacy and Support: Evidence from a West German Panel Study', Journal of Politics, 49 (1987), 441-64, at p. 461.

${ }^{28}$ J. Maxwell Elden, 'Political Efficacy at Work: The Connection between More Autonomous Forms of Workplace Organization and a More Participatory Politics', American Political Science Review, 75 (1981), 43-58.

${ }^{29}$ Frey, 'A Constitution for Knaves Crowds Out Civic Virtues'; Frey and Stutzer, 'Happiness, Economy and Institutions'.

${ }^{30}$ Mendelsohn and Cutler, 'The Effect of Referendums on Democratic Citizens'.

${ }^{31}$ Cronin, Direct Democracy, p. 11. 
debates over the foundations of citizen attitudes towards government, and the issue of how such attitudes are rooted in institutional structures themselves. One question to be addressed before moving further is why direct democracy might have such a positive impact on voter attitudes.

By definition direct democracy gives people a chance to participate in decisions that formally shape public policy and, as we noted above, this has long been held by some democratic theorists to be of value. Both the opportunity to participate, as well as the act of participation on policy decisions, can be expected to promote more positive views about the efficacy of individual political activity. At one level, it gives the mass public an occasional voice in government and provides some means - at least in principle - of ensuring that the public is consulted (or anticipated) in discussions about major policy issues. Work on Canadian attitudes about government, for example, points to the importance of being 'listened to' as a factor that shapes citizen attitudes about representative government generally. ${ }^{32}$ In a sense direct democracy assures voters that government either is listening to them or has to listen to them at some point.

At a second level, direct democracy provides an additional mechanism for citizens to shape policy outcomes. Voting on policy provides citizens another method, in addition to representative government, for expressing their consent or opposition to what the government might do (or might not do). The degree to which government policy actually reflects voter desires is a matter of debate, yet there is some evidence that policy more closely matches mass preferences in the American states that use direct democracy than in those states that lack direct democracy. ${ }^{33}$ The effect of initiatives on policy could be direct, via voters approving legislation, or indirect, via pressure that the threat of initiatives places on legislators. In the realm of mass attitudes, however, part of what might matter is that voters simply believe their voices will be heard by public officials when citizens vote directly on issues. Likewise, they may believe they are heard in ways perceived to be qualitatively different than they are when their

${ }^{32}$ F. Graves, with T. Dugas and P. Beauchamp, 'Identity and National Attachments in Contemporary Canada (1)', in Harvey Lazar and Tom McIntosh, eds, Canada: The State of the Federation 1998-99 (Kingston, Ont.: Institute for Intergovernmental Relations, Vol. 13: How Canadians Connect, forthcoming).

${ }^{33}$ For evidence, see Elizabeth Gerber, 'Legislative Response to the Threat of Popular Initiatives', American Journal of Political Science, 40 (1996), 99-128; Elizabeth Gerber, 'Legislatures, Initiatives, and Representation: The Effects of State Legislative Institutions on Policy', Political Research Quarterly, 49 (1996), 263-86; John Matsusaka, 'Fiscal Effects of the Voter Initiative: Evidence from the Last 30 Years', Journal of Political Economy, 103 (1995), 587-623. In contrast, see Edward Lascher, Michael Hagen and Steven Rochlin, 'Gun Behind the Door? Ballot Initiatives, State Policies and Public Opinion', Journal of Politics, 58 (1996), 760-75; John Camobreco, 'Preferences, Fiscal Policies and the Initiative Process', Journal of Politics, 60 (1998), 819-29. For a related discussion of how PR election laws may bring legislators closer to voter preferences than SMD election laws, see G. Bingham Powell Jr. and Georg S. Vanberg, 'Election Laws, Disproportionality and Median Correspondence: Implications for Two Visions of Democracy', British Journal of Political Science, 30 (2000), 383-411. 
participation is limited to selecting representatives once every few years. When voting directly on initiatives and referendums, they may be one step closer to affecting policy outcomes than when they vote for candidates.

Institutions of direct democracy thus provide a political context where many citizens must consider and decide upon public issues and policies - at least relatively more so than in a standard electoral context. Where initiatives appear frequently on state ballots, it is more likely that active campaigns or media coverage might focus public attention on a major public issue or set of issues. In such an environment, citizens may feel more competent about their political skills as they receive more policy-relevant information than would have otherwise been the case, at least at some minimal level. Many voters who participate on ballot questions will also deliberate about how to vote on issues by using multiple sources of information and by seeking out cues about who supports or opposes the measure. ${ }^{34}$

Frey's argument goes further than this. He argues that in allowing citizens to participate in policy decisions, direct democracy bolsters civic virtues since the very system tells voters they are to be trusted. When treated as trustworthy, voters respond by being less cynical. The institution of direct democracy represents a constitutional expression of trust in citizens, in contrast to the more familiar constitutional expressions of mistrust. ${ }^{35}$

\section{HYPOTHESES}

One of the main hypotheses of interest, then, is that experience with direct democracy should promote more positive attitudes about the prospects for, and consequences of, citizen participation in the political system. Since we expect that institutions which provide extra-legislative opportunities for mass influence on policy are most relevant to the discussion above, we focus on experience with direct citizen initiatives in the states, rather than legislative referendums. And since it is relative levels of exposure to the practice of direct democracy that we expect to be of consequence, we treat direct democracy as a continuous variable here. ${ }^{36}$ Some states have formal mechanisms for use of the initiative, yet barriers such as court scrutiny and/or qualification hurdles can be such that, in practice, initiatives are rarely used in places where the institution exists (such as Illinois, Mississippi and Wyoming). Other states allowing the initiative have much more

34 Arthur Lupia, 'Shortcuts Versus Encyclopedias: Information and Voting Behavior in California Insurance Reform Elections', American Political Science Review, 88 (1994), 63-76; Bowler and Donovan, Demanding Choices.

${ }^{35}$ Frey, 'A Constitution for Knaves Crowds Out Civic Virtues,' pp. 1048-9.

${ }^{36}$ Our models were also estimated with an ordinal measure of initiative use, found in Caroline Tolbert, 'Changing Rules for State Legislatures', in Shaun Bowler, Todd Donovan and Caroline Tolbert, eds, Citizens as Legislators: Direct Democracy in the United States (Columbus: Ohio State University Press, 1998), pp. 180-1. The substantive results remain the same. Interval measures are more readily interpreted, so those are reported here. 
experience with the process, although there is great variation in use, with California, North Dakota and Oregon having used initiatives most frequently. ${ }^{37}$

One of the only existing studies to examine the relationship between direct democracy and Americans' attitudes about government ${ }^{38}$ examined state-level attitudes in aggregate, while treating the presence of direct democracy as a simple dichotomy. This method failed to detect differences across states. However, if actual exposure to direct democracy leads citizens to have a greater sense that they can influence government, we should expect that frequency of initiative use $\mathrm{s}^{39}$ in a citizen's state explains some variation in individual-level attitudes about political efficacy. We expect more initiatives generally to lead to greater efficacy, but we also examine whether this relationship is non-linear. It may be that modest levels of initiative use increase efficacy, but beyond some point citizens may be overwhelmed - very high levels of use thus might cause them to feel less capable of having influence.

Running counter to this are two broad lines of argument. First, variants of this 'opportunities for participation breeds efficacy' hypothesis have had a disappointing history. Real-world voters are often not nearly as responsive to the opportunities to participate as academics and intellectuals would like. ${ }^{40}$ The underwhelming track record of American mass political participation, and uniformly low levels of trust in government in the United States, ${ }^{41}$ suggest that the null hypothesis offers a fairly good chance of being supported in the American context.

Secondly, the general literature on public regard for government tells us we must also account for rival hypotheses about other institutional effects that may well swamp that of direct democracy. One key factor is whether the voter supported candidates who lost in recent elections. That is, if the voter's preferred candidates for office lost at election time, then the voter might come to feel that she has less 'voice' in government and could be correspondingly gloomier about the responsiveness of government to her needs. ${ }^{42}$ Contrary to Pateman's theory that greater participation in decisions will make citizens 'better' at democratic participating, ${ }^{43}$ the fact that a citizen is on the losing side of decisions might make her lose interest in politics, or at least lead her to have less sense that participation has positive consequences. State level variation in electoral results

${ }^{37}$ For discussion, see Caroline Tolbert, Daniel Lowestein and Todd Donovan, 'Election Law and Rules for Using Initiatives,' in Bowler, Donovan and Tolbert, eds, Citizens as Legislators, pp. 27-54.

38 Citrin, 'Who's the Boss?' p. 287.

${ }^{39}$ For a discussion of the advantages of measuring the use of direct democracy rather than the simple existence of formal provisions for its use, see A. Landner and M. Brandle, 'Does Direct Democracy Matter for Political Parties? An Empirical Test in the Swiss Cantons', Party Politics, 5 (1999), 283-302.

${ }^{40}$ However, see Morell, 'Citizens' Evaluations of Participatory Democratic Procedures'.

41 Craig, Broken Contract?

${ }^{42}$ Listhaug, 'Confidence in Political Institutions'; Norris, Critical Citizens; Anderson and LoTempio, 'Winning, Losing and Political Trust in America'; Clarke and Acock, 'National Elections and Political Attitudes'.

43 Pateman, Participation and Democratic Theory, p. 25. 
allows us to control for how individual voters stand in relation to the political system - as a 'winner' or 'loser' in terms of the candidates they supported at the top of the ballot.

Another hypothesis from the broader literature suggests that fragmented control of political institutions can affect citizens' perceptions of governmental responsiveness. Listhaug and Wiberg's cross-national work, for example, shows that aside from economic conditions, the factors which strongly influence the degree of voter confidence in European governments are the (short) duration of governments and the number of parties in government. Multi-party coalitions and short-lived governments are viewed more negatively. ${ }^{44}$ The rise and fall of coalition governments and interparty bickering among coalition partners are, of course, not to be found in the American states. A rough analogy, however, might be that of divided government: voters living in states with divided government may find it more difficult to perceive who is responsible for policy outcomes. This could cause them to be less likely to believe they can direct government or hold it accountable. They may also be more likely to have a gloomier view of the governmental process than voters living where unified party control makes for less partisan bickering - at least in principle.

In addition to these controls for rival institutional effects, models estimating attitudes about personal political abilities and governmental responsiveness should also include terms for individual-level factors known to affect efficacy generally. Political and attitudinal attributes should also be accounted for. Strong partisans for example, having a more coherent approach to viewing their political world, could be expected to have a greater sense of efficacy than independents and weak partisans. Economic evaluations have also been found to affect electoral support for government, ${ }^{45}$ and also affect general attitudes about trust in government. ${ }^{46}$

Age, likewise, has been found to be related to trust and confidence in government. Citizens in younger age cohorts have been shown to have more cynicism about their relationships with government, and thus can have lower levels of efficacy. ${ }^{47}$ Social characteristics such as gender, education and race are also expected to structure how individuals perceive their capacity to affect what government does. Women may perceive themselves as having less influence in politics, leading them to be less likely to score high on efficacy measures. ${ }^{48}$ Formal education is expected to give citizens resources and skills that help them negotiate the political world, so higher levels of education are thus one of the

44 Listhaug and Wiberg, 'Confidence in Political and Private Institutions,' pp. 310-11.

45 For a review, see Michael Lewis-Beck, Economics and Elections: The Major Western Democracies (Ann Arbor: University of Michigan Press, 1988).

${ }^{46}$ Hetherington, 'The Effect of Political Trust on the Presidential Vote, 1968-96'.

${ }^{47}$ M. Kent Jennings and Richard Niemi, Generations and Politics (Princeton, NJ: Princeton University Press, 1981).

${ }^{48}$ Paul Abramson, Political Attitudes in America: Formation and Change (San Francisco: Freeman, 1983). 
main determinants of higher levels of political efficacy. ${ }^{49}$ The relationship between race (and minority ethnicity), direct democratic institutions and efficacy may be complex. Several highly visible ballot initiatives have targeted legislative policies that advanced minority interests ${ }^{50}$ and campaigns might turn mass opinions against minorities targeted by initiatives. ${ }^{51}$ This might lead minorities to have less efficacy where they are more frequently exposed to initiative politics.

\section{MODEL SPECIFICATION}

The existing literature has demonstrated that political efficacy is a multidimensional phenomena, with two unique dimensions encompassing views of personal political abilities, or internal efficacy, and political influence, or external efficacy. ${ }^{52}$ The 1992 American National Election Study (NES) provides a fine opportunity to study factors that affect citizen attitudes on each of these dimensions. ${ }^{53}$ In addition to standard questions about governmental responsiveness to citizens, the 1992 post-election study included a larger than usual array of questions on attitudes about the individual's sense of his or her own political abilities, and thus provides instruments that tap both internal and external political efficacy. A report on the first use of these measures in the 1987 NES Pilot Study and 1988 NES post-election study found that the items we use as measures of internal efficacy represent a single concept distinct from external efficacy and political trust. ${ }^{54}$

${ }^{49}$ For evidence of the effect of education on efficacy, see Sidney Verba, Nancy Burns and Kay Schlozman, 'Knowing and Caring about Politics: Gender and Political Engagement,' Journal of Politics, 59 (1997), 1051-72; Paul Abramson, Political Attitudes in America (San Francisco, Freeman, 1983); Carol Cassel and David Hill, 'Explanations of Turnout Decline: A Multivariate Test', American Politics Quarterly, 9 (1981), 181-95; Bernadette Hayes and Clive Bean, 'Political Efficacy: A Comparative Study of the United States, West Germany, Great Britain and Australia', European Journal of Political Research, 23 (1993), 261-80.

50 Examples since the 1960s include measures attacking fair housing, desegregation of accommodation, school busing, welfare services, and affirmative action. For evidence of the adverse effects of initiatives on minorities, see Barbara Gamble, 'Putting Civil Rights to a Vote', American Journal of Political Science, 91 (1997), 245-69, and Derrick Bell Jr, 'The Referendum: Democracy's Barrier to Racial Equality', Washington Law Review, 54 (1978), 1-29. In contrast, see Bruno Frey and L. Gotte, 'Does the Popular Vote Destroy Civil Rights?' American Journal of Political Science, 42 (1998), 1343-8 and Todd Donovan and Shaun Bowler, 'Direct Democracy and Minority Rights: An Extension', American Journal of Political Science, 42 (1998), 1020-5.

51 James Wenzel, Todd Donovan and Shaun Bowler, 'Direct Democracy and Minorities: Changing Attitudes about Minorities Targeted by Initiatives', in Bowler, Donovan and Tolbert, eds, Citizens as Legislators, pp. 228-48.

52 Abramson, Political Attitudes in America; Balch, 'Multiple Indicators in Survey Research'; Lane, Political Life.

53 The 1992 NES sample includes respondents who were part of a multi-wave panel study. Since repeated exposure to surveys about politics might bias measures of political efficacy, we have limited our sample to cases who were part of the 'fresh wave' of 1992 respondents (i.e., respondents who were not previously interviewed in an earlier wave of the panel).

54 Richard Niemi, Stephen Craig and Franco Mattei, 'Measuring Internal Political Efficacy in the 1988 National Election Study’, American Political Science Review, 85 (1991), 1407-13. 
We conducted a Principal Components Analysis of seven efficacy measures relevant to this study, and results indicate that there are two distinct factors that structure responses. The four questions designed to measure internal efficacy load on a single, unique factor, while the two external efficacy questions load on a second unique factor. ${ }^{55}$ This suggests strongly that each respective set of items measures unique attitudinal phenomena, and that the items can be used to construct distinct indices of internal and external efficacy.

Respondents were asked, for example, whether they felt government was too complicated for them to understand, whether they felt they were qualified to participate in politics, whether they thought they could do as good a job in public office as others, and whether they thought themselves to be better or less informed about politics than other people. We use the responses to these questions as separate dependent variables in our assessment of the effect of direct democracy on respondents' perceptions of their own personal capabilities as a citizen - or their internal efficacy. Scores on these four items are then summed to create a general index of internal efficacy. ${ }^{56}$

The 1992 NES survey also provides items that measure perceptions of how responsive government might be to citizens. For the second portion of our analysis, we use as our dependent variables two questions that ask respondents whether 'people like [them]' have any say in what government does, and whether government officials care about what 'people like [them]' think. These questions, we assume, are more likely to tap attitudes about external efficacy. Again, we use a summary index of these items to create a general measure of external efficacy. ${ }^{57}$

Our independent variables are divided into three broad categories. The first group tests for the effects of institutions on attitudes. We account for frequency of direct democracy use with data from Tolbert et al. on the number of times that initiatives appeared on state ballots since the original date a state adopted procedures for the initiative. ${ }^{58}$ Scores on this variable range from 0 for

55 See the web version of this article for this material.

${ }^{56}$ Cronbach's $\alpha$ for the four-iterm internal efficacy index is 0.76 . See the web version of this article for an appendix that includes question wording and codings.

${ }^{57}$ Cronbach's $\alpha$ for the two-term external efficacy index is 0.68 . We also estimated models of these indices using factor scores from the respective internal efficacy and external efficacy components generated from the Principal Components Analysis. This produced no substantive change in our results. Estimates of the indices allow for more straightforward interpretation of effects. See the web version of this article for an appendix that includes question wording and codings, as well as the principle component analysis results.

58 Tolbert, Lowenstein and Donovan, 'Election Law and Rules for Using Initiatives', in Bowler, Donovan and Tolbert, eds, Citizens as Legislators, p. 29. An alternative version of our model was estimated with a measure of state initiative use limited to 1980-92, rather than frequency of use since adoption. Hypothesis tests using that model produced results identical to what is reported in Tables 1 and 2 . When the model was estimated using a dummy term for the effect of initiatives (where $1=$ the state allows initiatives), the effect for direct democracy is generally significant, but less consistent than what is reported here. Model fit is slightly higher when frequency of use is used rather than a dummy term. 
non-initiative states (and Mississippi) to between 3 to 274 for initiative states. ${ }^{59}$ We use this rather than the number of initiatives on a state's ballot at the time of the survey because we believe it is the cumulative effect of exposure to direct democracy that should shape citizen attitudes. ${ }^{60} \mathrm{~A}$ respondent's status as a 'loser' in elections is represented by a variable coded 1 to represent respondents who voted for a losing presidential candidate in 1992. Likewise, a similar dummy term reflects whether the candidate who won the 1992 US Senate seat in the respondent's state came from a party other than the party the respondent identified with. Residence in states where control of the legislature was divided between parties, or where different parties controlled the governor's office and at least one legislative chamber, was also represented with a dummy variable.

The second category of variables account for political and attitudinal factors that might affect efficacy. We include dummy terms for strong Democrats, strong Republicans and independents who do not lean to either party. The reference category is thus weak partisans and independents who 'lean' towards either party. These citizens have less interest in politics, and we expect them to have less efficacy as a result of their low interest and weak ties to parties. ${ }^{61}$ The model also includes measures of state and national economic evaluations (where high scores reflect economic worries).

The final category of variables represent social and demographic factors discussed above (age, gender, race and education). ${ }^{62} \mathrm{We}$ include an interaction between race (non-white) and initiative use to test if direct democracy reduces the political efficacy of non-whites. ${ }^{63}$ It is also possible that cultural or regional effects might structure individual efficacy, and these effects could covary with a state's use of direct democracy. States that use initiatives more frequently, for

59 Respondents from thirty-three states were included in the NES sample. Of the 1,126 total cases, 41 per cent are drawn from thirteen different initiative states. These include California ( 9.6 per cent of all cases), Michigan (6.4 per cent), Arizona (5.6 per cent), Florida (4.6 per cent), Massachusetts (3.5 per cent), Illinois (2.8 per cent), Missouri (2.3 per cent), Ohio (1.5 per cent), Arkansas (1.2 per cent), Oregon (1.1 per cent), Colorado ( 1.1 per cent), Washington ( 0.9 per cent), and Wyoming (0.6 per cent). Arkansas, Arizona, Colorado, California, Massachusetts, Oregon and Washington score high on either measure of initiative use.

${ }^{60}$ States with most frequent use of initiatives over this period are: Oregon (274), California (232), North Dakota (160), Colorado (150), Arizona (133), Washington (91), Arkansas (80), Oklahoma (79), Missouri (60) and Ohio (58).

${ }^{61}$ Empirically, there is no distinction between the low levels of interest of weak partisans and independents who lean towards a party. We use 'pure' independents as a dummy variable (rather than as our reference category) as they are distinguished from weak partisans and independents who lean by lower levels of participation. See William Flanigan and Nancy Zingale, Political Behavior of the American Electorate (Washington, DC: Congressional Quarterly Press, 1998), pp. 77-9.

62 See the web version of the paper for codings of these variables.

63 The non-white category includes Latinos. All models reported here were also estimated with an additional variable controlling for respondent's income (V924105). Significance tests for our main hypotheses are unchanged when income is included. Model fit with income is lower in five of the eight estimations reported here. Due to this, and the fact that refusals on this question reduce the sample, models are reported without income. 
example, could have a political history and culture that led them to adopt the initiative, and that history might still affect contemporary political behaviour and attitudes. ${ }^{64}$ Likewise, western states that make more frequent use of the initiative tend to have greater in-migration, which could also covary with a more efficacious population. Each factor could cause an observed relationship between initiative use and efficacy to be spurious.

We control for these factors by including an ordinal measure derived from Daniel Elazar's assessment of distinct American regional cultures that are defined by decades of migration patterns. Scores representing each state's political culture range over a nine-point continuum from 'moralistic' to 'traditionalistic. ${ }^{65}$ Residents of states with moralistic cultures (parts of New England, and much of the west) are expected to place greater value on participation, particularly 'amateur' and non-partisan participation, ${ }^{66}$ whereas residents of traditionalist states (much of the south) may accept more elitism and hierarchy. ${ }^{67}$ If residents of moralistic states have greater familiarity with or regard for participatory politics we might expect them to have higher levels of efficacy.

\section{RESULTS}

We have coded the dependent variables such that higher scores are associated with a more efficacious reply. Looking first at the Ordinary Least Squares (OLS) coefficients generated from our models, we find evidence in Table 1 that respondents in states that frequently use direct democracy are more likely to claim they have resources and skills that we might expect to be advantageous - or at least desirable - for democratic citizens. They are more likely to claim to have a good understanding of political issues, are more likely to consider themselves qualified to participate in politics, and are more likely to feel that they are better informed about politics than other people. The one test that fails to reject the null hypothesis about direct democracy is in the expected direction, but fails to attain statistical significance. On balance, however, the estimate of the summary index of internal efficacy demonstrates that respondents are more

${ }^{64}$ For a discussion of this thesis, and of the geographic distribution of distinct political cultures, see Daniel Elazar, American Federalism: A View from the States (New York: Harper and Row, 1984).

${ }^{65}$ For the state culture measure, see Ira Sharkansky, 'The Utility of Elazar's Political Culture: A Research Note', Polity, 2 (1969), 66-83. For other applications of this variable, see David Lowery and Lee Sigelman, 'Political Culture and State Public Policy: The Missing Link', Western Political Quarterly, 35 (1982), 376-84; John Baker, 'Exploring the "Missing Link": Political Culture as an Explanation of the Occupational Status and Diversity of State Legislators', Western Political Quarterly, 43 (1990), 597-611. Elazar also includes an 'individualistic' culture in the centre of this continuum, and suggests (at p. 136) that the measure is one dimensional, as does Sharkansky (at p. 70).

66 Elazar, American Federalism, at p. 118.
67 Elazar, American Federalism, at p. 119. 
likely to see themselves as competent citizens when living in an institutional context that makes active use of direct legislation. These findings stand in contrast to studies of participation in representative elections that find voting to have no effect on internal efficacy. ${ }^{68}$

An alternative version of the model (not reported in the table) used a non-linear specification for frequency of initiatives to test if the effect on efficacy is muted or reversed at higher-levels of use ${ }^{69}$ For each internal efficacy item, as well as the internal efficacy index, the non-linear terms were statistically insignificant. On one item (qualified to participate), the initial non-linear specification was significant. This effect, however, appears to be driven by respondents from California, one of the highest initiative-use states. When a dummy variable representing California is added to the linear and non-linear estimation of this attitude, the non-linear effect of initiative use becomes insignificant while the linear effect continues to predict positive attitudes about being qualified to participate. Californians, however, are significantly less likely to see themselves as well qualified in an estimation of the linear effect of initiative use, but they do not differ from the rest of the sample on all other measures of internal or external efficacy. When the California dummy is added to each of the other estimations (not reported here), there is no significant effect for California, and the linear effects of initiative use on efficacy reported in Table 1 remain unchanged. ${ }^{70}$ Thus, apart from the single estimation finding that Californians feel less qualified, there is no evidence that initiative use has reached levels that have a negative impact on our measures of efficacy.

The substantive magnitude of the effect of initiative use on a respondent's internal efficacy index score in Table 1 (0.0056) can be expressed when the coefficient is multiplied by a state's use of initiatives. For example, the mean score on the internal efficacy index is 11.3. With all independent variables held constant a respondent from California (a high initiative use state) had a score about 1.3 points higher than a respondent from New York (which has no initiatives). ${ }^{71}$ Residence in a state with a history of high initiative use then, is associated with an internal efficacy score about 10 per cent beyond the mean. In contrast a one category increase on the education measure - which is equal to the difference between having a two-year or a four-year college degree - is associated with a score 0.811 points higher (or about 8 per cent above the mean). ${ }^{72}$

${ }^{68}$ Finkel, 'The Effects of Participation on Political Efficacy', p. 461; Finkel, 'Reciprocal Effects of Participation on Political Efficacy', p. 908.

69 Where $Y==\mathrm{a}+\beta^{*}$ (frequency) $-\beta^{*}$ (frequency*frequency) $+\beta^{*} X_{\mathrm{n}} \ldots$

70 The same is true when non-linear estimates, and estimates with dummy variables for California, are used to re-estimate the models reported in Table 2 . The non-linear specification and the addition of dummies for California, moreover, do nothing to improve model fit beyond the linear specification reported in Table 1 or Table 2.

${ }^{71}$ California's historic experience equals 232 initiatives $(232 * 0.0056=1.29)$.

72 The education measure is an ordinal rather than interval measure. Thus, it cannot be known if the effect of a change from 3 (high school completed) to 4 (some education beyond high school but no higher degree) on the scale is the same as a change from 5 (an AA degree) to 6 (a BA/BS degree). 
There are also some notable effects for other institutional factors here. Respondents who identified with a party whose US Senate candidate was defeated in their state are generally less efficacious. Having voted for one of the losing presidential candidates is also associated with lower levels of internal efficacy on all but one of the measures. We also find that living in a state with divided government is associated with feeling less informed. The effects of being a loser in the electoral arena and residing in a state with divided government run in the opposite direction of the effects of direct democracy in every estimation, but the effect of divided government on the index of internal efficacy is not significant.

Among variables that account for political/attitudinal factors, there is evidence in most estimations that lack of a strong party anchor (represented by 'pure independents') is associated with less efficacy. Most of the variables that account for social and demographic traits are also important, with education and gender significant in every estimation. Increased education, as anticipated, provides a significant boost to citizens' perceptions of their political abilities. The effects of race and age appear to be less consistent, with race having little influence. There is partial evidence, however, that frequent use of direct democracy may have an adverse effect on non-whites' perceptions of their capabilities as citizens. The interaction term reflects that non-whites are less likely to see government as uncomplicated if they live in states that use initiatives more frequently. Non-whites residing in higher-use initiative states also have lower scores on the summary index of internal efficacy, but the effect is not statistically significant. The measure controlling for state political culture, furthermore, is also related to internal efficacy. Contrary to our expectations, respondents living in traditionalistic states are more confident that they are qualified to participate and do a good job in office, and score higher on the internal efficacy measure than residents of the most moralistic states. The important point here is that the indicator of state initiative use remains a significant predictor of efficacy even when variation in state culture - as defined by historic migration patterns - is accounted for. ${ }^{73}$

Table 2 illustrates that our estimates of external efficacy - or perceptions of governmental responsiveness - also support the hypothesis that more frequent direct democratic practice leads citizens to have a greater sense that government is responsive. Citizens residing in higher-use initiative states are more likely to claim that 'people like [them]' have a say about what 'the government' does, and are more likely to claim that 'public officials' care about what 'people like [them]' think. As in Table 1, non-linear specifications of the effect of initiative

${ }^{73}$ A discussion about why residents of traditionalistic states have higher efficacy is beyond the scope of this article. The effect of initiative use remains the same when this variable is included or omitted. We should also note that these models were re-estimated with a measure of state-level residential mobility (100 - per cent born in state, 1990). This variable was not significant in any estimation. It was mildly collinear with the state culture measure, and is not included in the results reported here. 


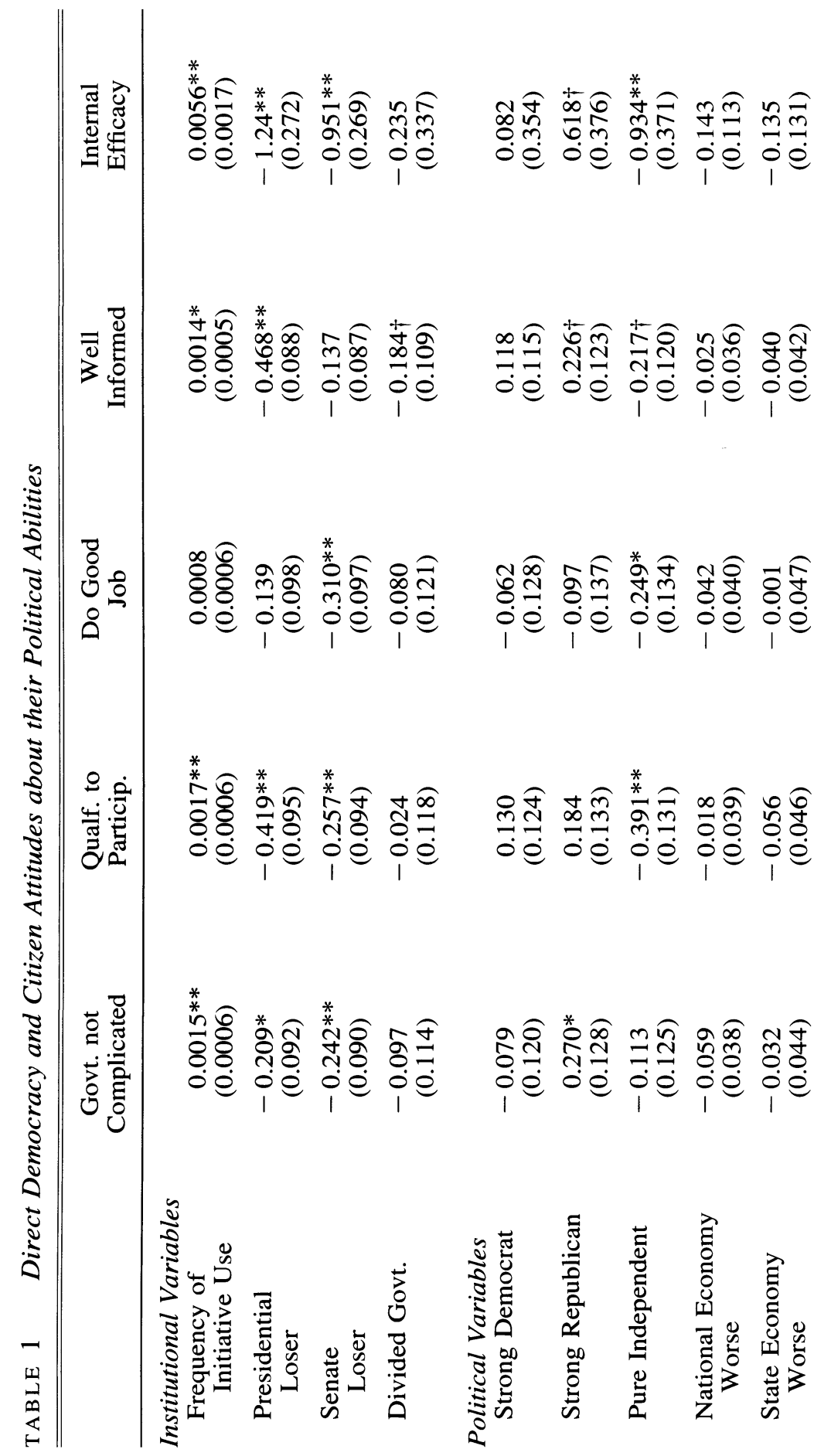




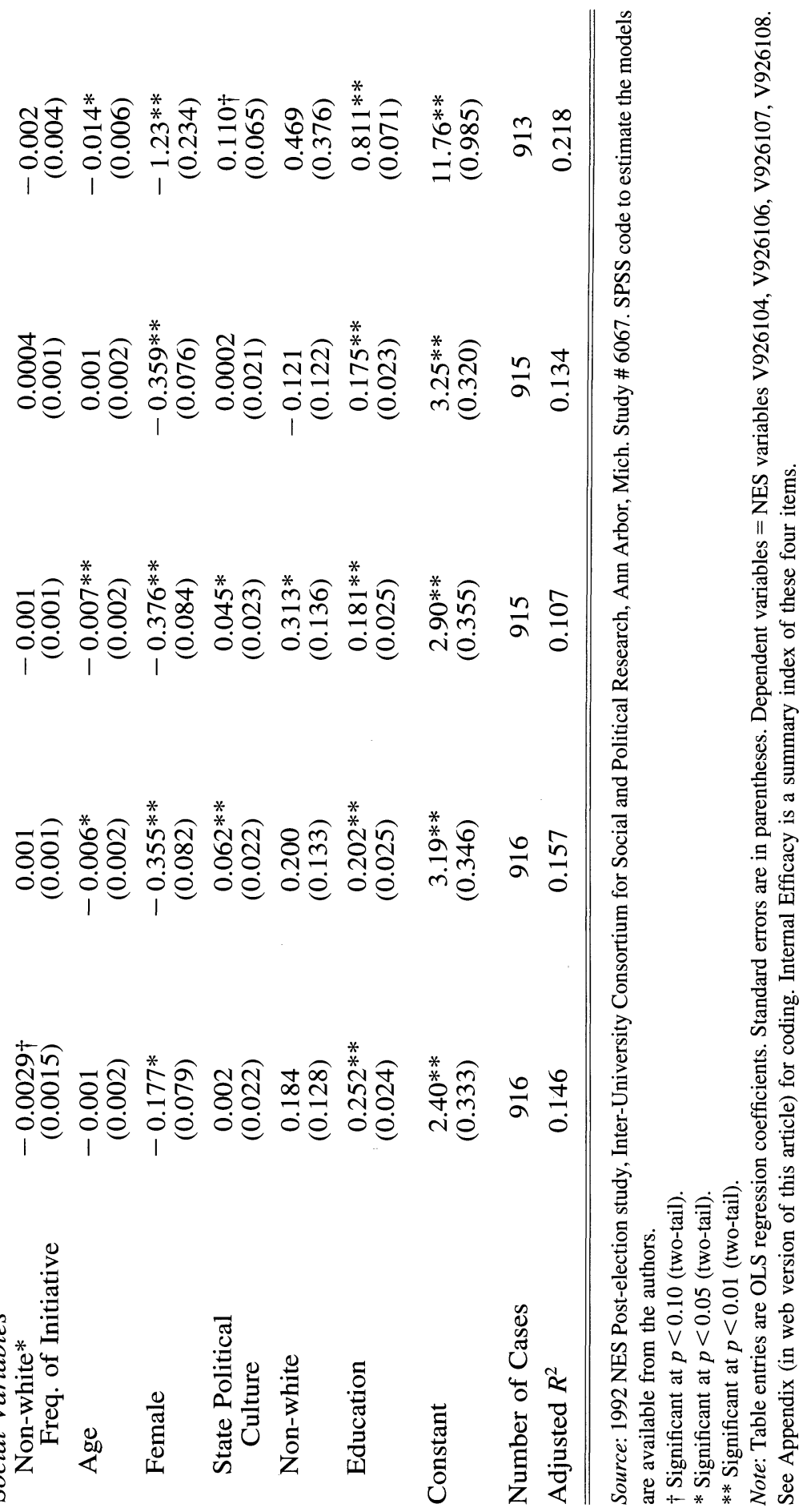


TABLE 2 Direct Democracy and Citizen Attitudes about Governmental Responsiveness

\begin{tabular}{|c|c|c|c|}
\hline & $\begin{array}{l}\text { Has Say } \\
\text { in Govt. }\end{array}$ & $\begin{array}{l}\text { Officials } \\
\text { Care }\end{array}$ & $\begin{array}{l}\text { External } \\
\text { Efficacy }\end{array}$ \\
\hline \multicolumn{4}{|l|}{ Institutional Variables } \\
\hline $\begin{array}{l}\text { Frequency of } \\
\text { Initiative Use }\end{array}$ & $\begin{array}{l}0.0022 * * \\
(0.0006)\end{array}$ & $\begin{array}{l}0.0012 * \\
(0.0006)\end{array}$ & $\begin{array}{l}0.0026 * * \\
(0.0008)\end{array}$ \\
\hline Presidential & $-0.312 * *$ & $-0.401 * *$ & $-0.377 * *$ \\
\hline Loser & $(0.105)$ & $(0.097)$ & $(0.134)$ \\
\hline Senate & -0.053 & -0.045 & -0.098 \\
\hline Loser & $(0.103)$ & $(0.096)$ & $(0.132)$ \\
\hline Divided Govt. & $\begin{array}{c}-0.349^{* *} \\
(0.130)\end{array}$ & $\begin{array}{r}-0.198 \dagger \\
(0.120)\end{array}$ & $\begin{array}{c}-0.436^{* *} \\
(0.166)\end{array}$ \\
\hline \multicolumn{4}{|l|}{ Political Variables } \\
\hline Strong Democrat & $\begin{array}{r}-0.020 \\
(0.136)\end{array}$ & $\begin{array}{r}-0.054 \\
(0.127)\end{array}$ & $\begin{array}{c}0.026 \\
(0.175)\end{array}$ \\
\hline Strong Republican & $\begin{array}{c}0.133 \\
(0.146)\end{array}$ & $\begin{array}{l}0.342 * \\
(0.136)\end{array}$ & $\begin{array}{r}-0.018 \\
(0.187)\end{array}$ \\
\hline Pure Independent & $\begin{array}{r}-0.091 \\
(0.144)\end{array}$ & $\begin{array}{c}0.005 \\
(0.133)\end{array}$ & $\begin{array}{r}-0.187 \\
(0.183)\end{array}$ \\
\hline National Economy & $-0.110^{*}$ & $-0.083^{*}$ & $-0.143^{*}$ \\
\hline Worse & $(0.043)$ & $(0.040)$ & $(0.056)$ \\
\hline State Economy & -0.055 & $-0.118 *$ & -0.032 \\
\hline Worse & $(0.050)$ & $(0.047)$ & $(0.064)$ \\
\hline \multicolumn{4}{|l|}{ Social Variable } \\
\hline $\begin{array}{l}\text { Non-white* } \\
\text { Freq. of Initiative }\end{array}$ & $\begin{array}{r}-0.001 \\
(0.001)\end{array}$ & $\begin{array}{r}-0.0029 \dagger \\
(0.0016)\end{array}$ & $\begin{array}{r}-0.001 \\
(0.002)\end{array}$ \\
\hline Age & $\begin{array}{r}-0.001 \\
(0.002)\end{array}$ & $\begin{array}{l}0.001 \\
(0.002)\end{array}$ & $\begin{array}{r}-0.004 \\
(0.003)\end{array}$ \\
\hline Female & $\begin{array}{r}-0.022 \\
(0.090)\end{array}$ & $\begin{array}{c}0.159 * \\
(0.083)\end{array}$ & $\begin{array}{c}-0.081 \\
(0.115)\end{array}$ \\
\hline $\begin{array}{l}\text { State Political } \\
\text { Culture }\end{array}$ & $\begin{array}{r}-0.043 \dagger \\
(0.025)\end{array}$ & $\begin{array}{r}-0.031 \\
(0.023)\end{array}$ & $\begin{array}{r}-0.047 \\
(0.032)\end{array}$ \\
\hline Non-white & -0.031 & -0.019 & 0.040 \\
\hline Education & $\begin{array}{l}(0.145) \\
0.192 * * \\
(0.027)\end{array}$ & $\begin{array}{c}(0.135) \\
0.142 * * \\
(0.025)\end{array}$ & $\begin{array}{l}(0.186) \\
0.128 * * \\
(0.035)\end{array}$ \\
\hline Constant & $\begin{array}{c}3.97 * \\
(0.380)\end{array}$ & $\begin{array}{l}3.24 * * \\
(0.352)\end{array}$ & $\begin{array}{c}6.69 * * \\
(0.487)\end{array}$ \\
\hline Number of cases & 916 & 913 & 913 \\
\hline Adjusted $R^{2}$ & 0.083 & 0.075 & 0.081 \\
\hline
\end{tabular}

Source: 1992 NES Post-election study, Inter-University Consortium for Social and Political Research, Ann Arbor, Mich. Study No. 6067. SPSS code to estimate the models is available from the authors.

$\dagger$ Significant at $p<0.10$ (two-tail). $*$ Significant at $p<0.05$ (two-tail). ${ }^{* *}$ Significant at $p<0.01$ (two-tail).

Note: Table entries are OLS regression coefficients. Standard errors are in parentheses. Dependent variables $=$ NES variables V926102 and V926103. The index is a sum of these two variables (see Appendix in web version of paper for coding). 
use on external efficacy (not reported) were statistically insignificant. Thus, we find no clear evidence that a history of high levels of initiative use might overwhelm citizens.

Again, the substantive magnitude of the effect of initiative use is not trivial, particularly when compared to the relatively limited effect that variation in formal education has on external efficacy. Consider that the mean score on the summary index of external efficacy is 5.4. Using estimates of this index from Table 2, a respondent from California would be predicted to have a score 0.6 points higher ${ }^{74}$ than a respondent from a non-initiative state. If this effect is considered as added to the mean external efficacy score, it would produce a score 11 per cent above the mean. A shift from a two-year to a four-year degree (or from a BA/BS to an advanced degree), in contrast, is associated with only a 0.127 increase on the external efficacy index, which is equal to being about 2 per cent above the mean. With one of the external efficacy items, however, the effect of frequent use of initiatives operates differently on non-whites. Non-whites living in states that use more initiatives are less likely to claim that 'public officials' care about what they think. This is consistent with the hypothesis that direct democracy, by producing outcomes that harm minorities, has a negative effect on minority citizens' attitudes about having influence in government.

Again, in Table 2 we also see that presidential electoral outcomes shape a citizen's perceptions of how responsive the government is to them personally. Respondents living in states with divided government are significantly less likely to claim they have a say. Overall, however, our models do a better job explaining variance in internal efficacy than external efficacy. Gender, age and lack of strong partisanship, which were significant in most estimations of internal efficacy, have less of a role in estimates of external efficacy.

\section{DISCUSSION}

Our findings are consistent with the theory that direct participatory models of democracy may encourage a greater sense of efficacy, and possibly, civic engagement. People living in states that use more initiatives tend to have more positive views of their own political abilities and look more favourably on the responsiveness of government. We also find a pattern that is consistent with recent work examining how democratic institutions influence citizens' perceptions of politics. Being on the losing side of candidate elections tends to make citizens have less positive attitudes about their political abilities and have less positive attitudes about governmental responsiveness.

Institutional effects are not the only things that shape a citizen's perceptions about how they influence government. Other factors, most notably education, also contribute to feelings of political efficacy. But the findings here indicate that use of state-level initiatives may contribute to American democracy generally by instilling a greater sense that citizens have the ability to shape what

${ }^{74}$ As in fn. $4(232 * 0.0026=0.603)$. 
their governments do. The substantive magnitude of the effect, moreover, rivals that of education, which has been demonstrated to be a consistent predictor of efficacy. ${ }^{75}$ An extension of our logic suggests that citizens who consistently see themselves on the losing end of initiative contests, like those on the losing end of candidate contests, may have lower levels of political efficacy. Although we do not have direct measures of a respondent's support for various ballot measures, we find some indirect evidence of this effect. Non-white respondents residing in initiative states are less efficacious on some, but not most, of the instruments used to measure efficacy here.

It remains to be established what effect this increased sense of efficacy may have on participation in politics, and on other attitudes. It is also difficult to establish whether our findings reflect citizen perceptions that are shaped by actual policies enacted via initiative (or via legislatures operating under the threat of initiatives), or whether attitudes merely represent some response to a less consequential 'sound and fury' of initiative politics. That is, a democratic process of 'assured listening' that provides only an illusion of political influence, without actually altering policies, may also shape attitudes. It is possible then, that citizens may receive a false sense of empowerment from the use of initiatives if ballot measures have no consequence on policy, or if these measures advance policies that are inconsistent with the preferences of most citizens in a state. We do not expect that this is the case, however. There is mounting evidence that direct democracy does influence legislative behaviour by encouraging legislators to adopt policies that more closely mirror mass preferences. ${ }^{76}$ It seems reasonable to expect that a significant number of citizens are aware of this in direct democracy states and, thus, feel a greater sense of political efficacy than citizens in non-initiative states. In an era when cynicism about politics is high, these findings should not be seen as trivial.

Finally, we must acknowledge two caveats. First, the causal argument we offered could be reversed. Citizens may use their rights to the initiative in places where they are more efficacious, rather than having such initiatives cause them to feel more competent. Since our data are drawn at the mass level, however, we expect that our findings reflect citizens responding to initiatives that they probably did not initiate. Secondly, the level of analysis we employ could affect our results. As noted above, initiatives have been used more frequently in the United States in recent decades while efficacy has been in decline. This would suggest that frequent use of direct legislation - although associated with cross-sectional differences at a point in time - probably does not arrest secular declines in citizen efficacy. Direct democracy as practised in the United States might thus explain important differences in citizen attitudes across space, but not necessarily across time.

\footnotetext{
75 On the effect of education on efficacy, see Verba, Burns and Schlozman, 'Knowing and Caring about Politics'; Abramson, Political Attitudes in America; Cassel and Hill, 'Explanations of Turnout Decline'; Hayes and Bean, 'Political Efficacy'.

${ }^{76}$ Gerber, 'Legislative Response to the Threat of Popular Initiatives'; Gerber, 'Legislatures, Initiatives, and Representation'; Matsusaka, 'Fiscal Effects of the Voter Initiative'.
} 